\title{
THE LICHENS OF THE KRASÍN NATURE RESERVE IN BIELE KARPATY MTS (WESTERN CARPATHIANS, SLOVAKIA)
}

\author{
Zuzana FAČKovcovÁ ${ }^{1 *}$ and Luca PAOLI ${ }^{2}$ \\ ${ }^{1}$ Plant Science and Biodiversity Centre, Slovak Academy of Sciences, \\ Dúbravská cesta 9, SK-84523 Bratislava, Slovakia; *zuzana.fackovcova@savba.sk \\ ${ }^{2}$ Department of Biology, University of Pisa, via Ghini 13, I-56126 Pisa, Italy
}

Fačkovcová, Z. \& Paoli, L. (2019): The lichens of the Krasín Nature Reserve in Biele Karpaty Mts (Western Carpathians, Slovakia). - Studia bot. hung. 50(2): 307-316.

\begin{abstract}
The outputs of a pilot lichenological survey of the protected area Krasín (Western Carpathian Mts) are given. The area harbours various habitats (calcareous outcrops, southern xerotherm slopes, oak woods with Quercus pubescens, and hornbeam-linden woods) providing suitable conditions for a wide range of epiphytic, saxicolous, and epigeic lichens. During the field survey, 72 lichen taxa were recorded. Five of them are considered as threatened in Slovakia and four of them as indicators of forest ecological continuity.
\end{abstract}

Key words: biodiversity, lichenized fungi, NATURA 2000, threatened species

\section{INTRODUCTION}

The protected area of Krasín (Nature Reserve since 1971, later included in Natura 2000 network as SKUEV0375, also recognised as important regional biocentre RBC30 Krasín) is situated in the southwestern part of the Carpathian Mts (Fig. 1), in altitudinal range $331-570 \mathrm{~m}$ a.s.l. The climate is moderately warm and humid (LAPIN et al. 2002) with average annual temperature $7-8{ }^{\circ} \mathrm{C}$ (ŠŤASTNÝ et al. 2002) and precipitation $700-800 \mathrm{~mm}$ (FAšKo \& Š ŤASTNÝ 2002). The area belongs to a part of the klippen belt with calcareous klippe, loosen by ablation of the softer rocks. The klippe is formed of Jurassic crinoidal limestones and represents an important palaeontological site due to the presence of numerous fossils (Mišík et al. 1994).

Until the middle of the 20th century, the area was utilised as pasture for goats. Deforested southern slopes of the massif with outcrops harbour several calcareous biotopes of conservation concern: rupicolous grasslands dominated by annuals and succulents of the Alysso-Sedion albi, Pannonian grasslands (Stipo-Festucetalia pallentis), semi-natural dry grasslands and scrubland facies (Festuco-Brometalia), medio-European scree of hill and montane levels, and rocky slopes with chasmophytic 
vegetation (Natura 2000 Database). Dominant elements of grasslands are Festuca valesiaca Schleich. ex Gaudin, F. pallens Host, and Brachypodium pinnatum (L.) P. Beauv., less common are Lactuca perennis L., Thymus pulegioides L., and Origanum vulgare L. On rubble, it grows the richest population of Orlaya grandiflora (L.) Hoffm. in the region. Besides this, typical rubble communities comprise Sedum spp., Acinos alpinus (L.) Moench, and Dalanum angustifolium (Ehrh.) Dostál. The area of Krasín also represents an important site for orchids occurrence. Open habitats are suitable for Orchis militaris L., Listera ovata (L.) R. Br., the shrubs for $O$. pallens L., Cephalanthera damasonium (Mill.) Druce, Epipactis atrorubens (Hoffm.) Besser., E. microphylla (Ehrh.) Sw., E. muelleri Godfery. In light oak wood, a population of vulnerable Orchis purpurea Huds. is developed. The western and northwestern slopes are covered with a young hornbeam-linden forest (Carpinus-Tilia) with Fagus sylvatica L. and Acer campestre L. ingrown. Significant populations of Corydalis cava (L.) Schweigg. et Körte and C. solida (L.) Clairv. occur there. Fragments of xerophytic oak woods dominated by Quercus pubescens Willd. are present on southern exposed locations (Natura 2000 Report).

Due to the lack of traditional grazing from the middle of the 20th century, opened rocky slopes were exposed to the intensive succession by Corylus avel-

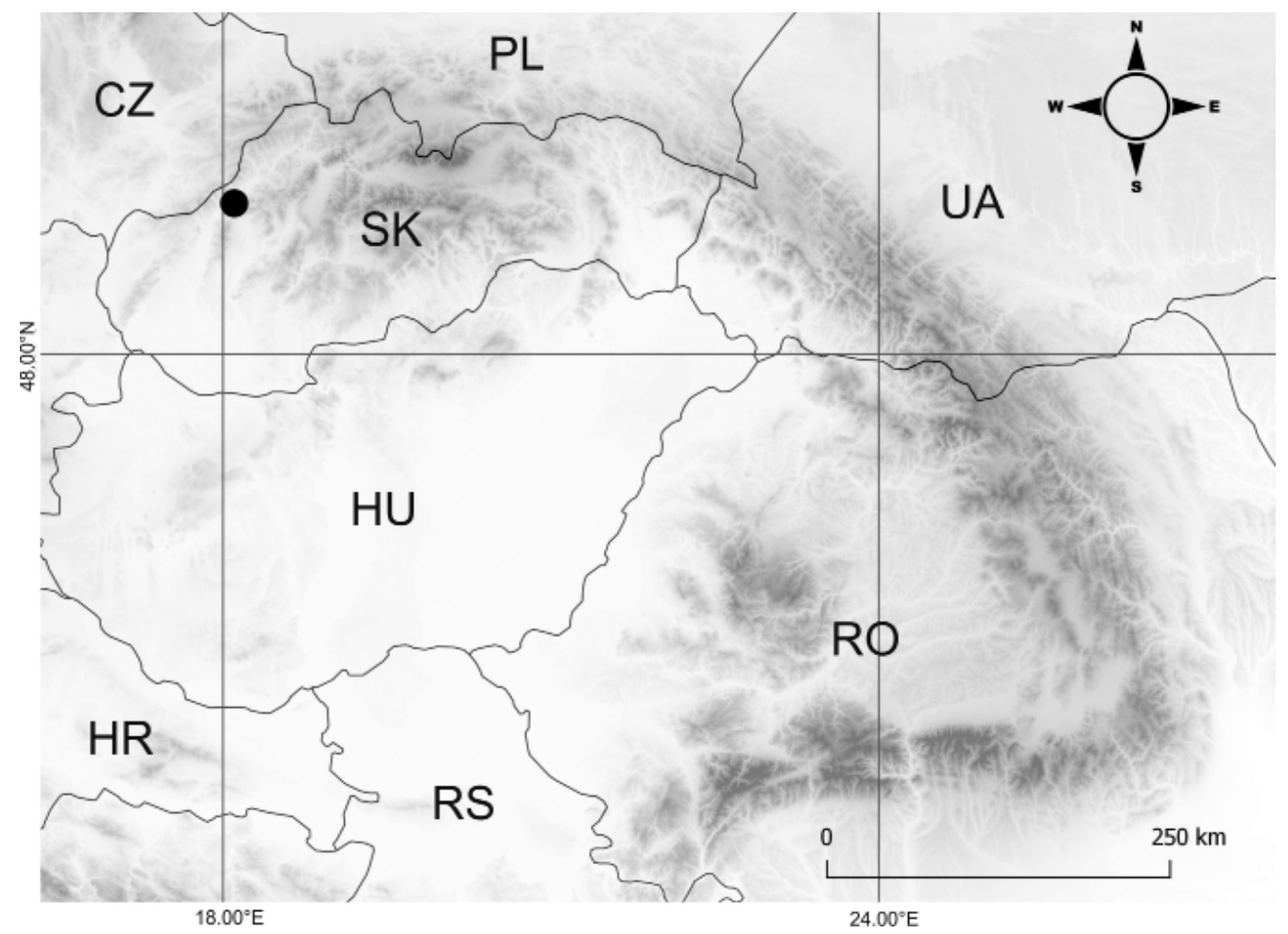

Fig. 1. Location of the Nature Reserve Krasín (black circle) within Carpathian Mts. 
lana L., Swida sanguinea (L.) Opiz, and Prunus spinosa L. and in the upper part of the hill also by an expansive native species Sambucus ebulus L. Since 1990, the shrubs have been regularly eliminated in order to preserve natural and seminatural grasslands. Other management strategies (e.g. annual mowing, retaining open canopy in Orchis purpurea sites, directing the tourism on educational trail) focus on conservation of EU priority biotopes, such as rocky "steppes" and valuable forests (Natura 2000 Report).

Despite the area is recognised for the occurrence of rare plant and animal species (Natura 2000 Database, Deván 2001, Lu Káš 2008, MajZlan 2017), lichenological data had been missing so far. The present paper thus represents the first contribution to the knowledge of the lichen flora in the Krasín Nature Reserve (NR).

\section{MATERIAL AND METHODS}

The lichenological survey was conducted based on a three-day field trip in 2014 within NR Krasín ( ca 27.16 ha). The localities were georeferenced by the coordination system WGS 84 . The wide spectrum of habitats, such as forests, grasslands, and calcareous outcrops was investigated in order to obtain information about the occurrence of epiphytic, epigeic, and saxicolous species. The specimens collected and identified by the authors are deposited in the herbarium of the Slovak Academy of Sciences in Bratislava (SAV). The lichen nomenclature follows GutTové et al. (2013) and its amendment available at http://ibot.sav. sk/lichens/checklist.html. The red list categories following IUCN criteria were considered according to the Red list of lichens of Slovakia (PIšút et al. 2001). The lichen flora was further characterised based on ecological indicator values of each species retrieved from NIMIS \& MARTELLOS (2017): the ecological traits (affinity to $\mathrm{pH}$ of the substratum, light requirements, xerophytism, tolerance to eutrophication, and poleotolerance) were analysed separately for epiphytic and saxicolous/epigeic lichens and expressed as percentages. On the basis of a 5-class ranking, according to the database of Nimis \& MARTELlos (2017), each species could be assigned to more than one class. For poleotolerance (three possible classes), each species has been assigned to a single class.

\section{List of localities}

Slovakia, Biele Karpaty Mts, Dolná Súča, NR Krasín:

1. sun-exposed calcareous outcrops in the western part of the massif, SW exposition, $470 \mathrm{~m}$ a.s.l., $31.5 .2014, \mathrm{~N} 48.95977^{\circ}$, E $18.01381^{\circ}$;

2. open calc-silicate rocks on the top, vertical cliff near transmitter, $\mathrm{N}$ exposition, $490 \mathrm{~m}$ a.s.1., $31.5 .2014, \mathrm{~N} 48.96043^{\circ}$, E 18.01521 ${ }^{\circ}$; 
3. sun-exposed calcareous outcrops on the edge of the hill, SE exposition, 550 m a.s.l., 31.5.2014, $\mathrm{N} 48.96178^{\circ}$, E $18.01915^{\circ}$;

4. calcareous outcrops in the E part of the massif, shaded mossy rocks in wood, $400 \mathrm{~m}$ a.s.1., 25.7.2014, $\mathrm{N} 48.96252^{\circ}$, E 18.02241 ${ }^{\circ}$;

5. NW slope of the massif with beech-hornbeam forest, $440 \mathrm{~m}$ a.s.1., 25.7.2014, $\mathrm{N} 48.96334^{\circ}, \mathrm{E} 18.02182^{\circ}$;

6. sun-exposed calcareous outcrops in the E part of the massif, SE slope, 420 $\mathrm{m}$ a.s.1., 25.7.2014, $\mathrm{N} 48.96251^{\circ}$, E $18.02188^{\circ}$;

7. NW slope of the massif, margin of beech-hornbeam forest, half-shaded, $480 \mathrm{~m}$ a.s.1., 19.7.2014, $\mathrm{N} 48.96063^{\circ}$, E $18.01508^{\circ}$;

8. NW slope of the massif with beech-hornbeam forest, $450 \mathrm{~m}$ a.s.l., 19.7.2014, N 48.96147 ${ }^{\circ}$, E $18.01670^{\circ}$;

9. touristic path on the edge of the hill, near transmitter, sun-exposed position, $490 \mathrm{~m}$ a.s.l., $31.5 .2014, \mathrm{~N} 48.96062^{\circ}$, E $18.01580^{\circ}$.

\section{RESULTS AND DISCUSSION}

The following 72 lichen taxa were recorded in the NR Krasín. Nine species are included in the red list and five of them are considered as threatened in Slovakia (PIšú t et al. 2001). The list of taxa is arranged alphabetically, numbers correspond to the localities. The type of substrate and deposition of specimen (if any) is listed in parentheses.

\section{List of taxa}

Acarospora cervina: 1 (on rock; -)

Agonimia opuntiella: 1 (among mosses on soil; SAV)

Amandinea punctata: 8 (on Crataegus sp.; SAV)

Arthonia radiata (CR): 8 (on Fagus sylvatica; SAV)

Bagliettoa cf. calciseda: 1 (on rock; SAV)

Bilimbia sabuletorum: 3 (among mosses on rock; SAV)

Caloplaca aurantia: 1 (on rock; SAV)

Caloplaca cirrochroa: 4 (on rock; SAV)

Caloplaca coronata: 1 (on rock; -)

Caloplaca crenulatella s. 1.: 1 (on rock; SAV)

Caloplaca flavescens: 1 (on rock; SAV)

Caloplaca chrysodeta: 3 (among mosses on rock; SAV)

Caloplaca saxicola s. 1.: 1 (on rock; SAV)

Caloplaca stillicidiorum agg.: 1 (on mosses; -), 3 (on mosses; SAV)

Caloplaca variabilis: 1 (on rock; SAV) 
Candelariella aurella: 1 (on rock; SAV)

Candelariella xanthostigma: 9 (on Quercus pubescens; -)

Catillaria lenticularis: 1 (on rock; -), 4 (on rock; SAV)

Catillaria nigroclavata: 7 (on Prunus spinosa; SAV)

Circinaria calcarea: 1 (on rock; -)

Circinaria contorta: 1 (on rock; SAV)

Cladonia pyxidata agg.: 3 (on soil; -)

Collema cristatum: 1 (on rock and among mosses on soil; -)

Collema fuscovirens: 1 (on rock and among mosses on soil; SAV)

Dermatocarpon miniatum: 1 (on rock;-)

Diploschistes muscorum: 1 (on mosses; SAV)

Diplotomma alboatrum (LR:nt): 1 (on rock; SAV)

Diplotomma venustum: 1 (on rock; SAV)

Endocarpon sp.: 6 (on rock; SAV)

Evernia prunastri (EN): 7 (on Prunus spinosa; -), 8 (on Acer sp.; -)

Graphis scripta (EN): 5 (on Fagus sylvatica; SAV)

Lecanora carpinea: 8 (on Fagus sylvatica; -)

Lecanora conizaeoides: 5 (on Fagus sylvatica; SAV)

Lecanora crenulata: 1 (on rock; SAV)

Lecanora dispersa: 1 (on rock; SAV)

Lecanora expallens: 8 (on Corylus sp.; -)

Lecanora saxicola: 1 (on rock; SAV)

Lecidella elaeochroma: 8 (on Corylus sp.; -)

Lecidella stigmatea: 1 (on rock; SAV)

Lepraria sp.: 2 (on Quercus pubescens; -)

Leptogium lichenoides: 1 (among mosses on soil; SAV)

Leptogium pulvinatum: 6 (on rock; SAV)

Leptogium schraderi: 1 (on rock; SAV)

Leptogium turgidum: 1 (among mosses on soil; SAV)

Lobothallia radiosa: 1, 6 (on rock; -)

Melanelixia glabratula: 2 (on Quercuspubescens; -), 5 (on Fagus sylvatica; SAV)

Parmelia sulcata: 9 (on Quercus pubescens; -)

Peltigera praetextata: 2 (on rock; -)

Peltigera rufescens: 1 (on soil; -), 4 (on soil; SAV)

Phaeophyscia nigricans: 9 (on Quercus pubescens; -)

Phaeophyscia orbicularis: 9 (on Quercus pubescens; -)

Phaeophyscia sciastra: 1 (on rock; -)

Physcia adscendens: 1 (on rock; -), 9 (on Quercus pubescens; -)

Physcia caesia: 2 (on rock; -)

Physcia stellaris: 7 (on Prunus spinosa; SAV) 
Placocarpus schaereri: 1 (on rock; -)

Placynthium nigrum: 6 (on rock; SAV)

Porina aenea: 5 (on Fagus sylvatica; SAV), 8 (on Corylus sp.; SAV)

Protoblastenia rupestris: 1, 6 (on rock; -), 4 (on rock; SAV)

Punctelia subrudecta (EN): 9 (on Quercus pubescens; -)

Pyrenula nitida (EN): 5 (on Fagus sylvatica; SAV)

Rinodina immersa: 1 (on rock; SAV)

Romjularia lurida: 1 (on rock; -)

Sarcogyne regularis: 1 (on rock; SAV), 3 (on rock; -)

Scoliciosporum chlorococcum: 5 (on Fagus sylvatica; SAV)

Squamarina cartilaginea (LR:nt): 1 (on rock; -)

Squamarina gypsacea (LR:nt): 6 (on rock; SAV)

Toninia sedifolia: 1 (on rock; -)

Verrucaria muralis: 1 (on rock; SAV)

Verrucaria nigrescens: 1 (on rock, -)

Verrucaria sp.: 4 (on rock; SAV)

Xanthoria parietina (LR:nt): 9 (on Quercus pubescens; -)

Calcareous rocks situated predominantly in the exposed southern slope of the hill harbour suitable habitats for saxicolous and epigeic lichen species. The most common lichens colonising such rocks are typical calciphilous species, e.g. Circinaria contorta, Collema cristatum, Lecanora saxicola, Lobothallia radiosa, Placocarpus schaereri, Protoblastenia rupestris, Romjularia lurida, Squamarina cartilaginea, etc. The xerothermic character of the sites is also demonstrated by the presence of thermophilous sub-Mediterranean species, such as Caloplaca aurantia, C. coronata, C. flavescens. Few thalli of the cyanolichens Leptogium schraderi and L. turgidum, scarcely recorded from Slovakia (GuTtová \& FAČKovcová 2012), have also been found in Krasín on the rocks and among mosses on soil. Since biotopes with overgrown grassland vegetation are not suitable for the development of epigeic lichens, they colonise mainly rock crevices where the occurrence of more competitive vascular plants is limited. In such crevices, mainly the species of Cladonia pyxidata agg. and Toninia sedifolia occur. Small squamules of an inconspicuous thermophilous (sub-Mediterranean) lichen (Agonimia opuntiella) growing over mosses were also recorded. Ecological indicator values for epigeic and saxicolous species (Table 1) reflect the lichen flora composed of xerothermic species, typical of sun-exposed sites on calcareous substrates and generally growing in moderately eutrophicated environments.

The epiphytic lichen biota is characterised mainly by the presence of nitrophilous species (e.g. abundant are Amandinea punctata, Phaeophyscia orbicularis, Physcia adscendens, Physconia grisea), but lacking extremely nitrophilous 
lichens (the only exception is Phaeophyscia orbicularis, Table 1). Acidophilous lichens, such as Lecanora conizaeoides and Scoliciosporum chlorococcum (widespread lichens in Slovakia in the second half of the 20th century; PIšút 1999) occur only rarely. The abundance of nitrophilous species and the reduction of acidophilous ones reflect the decreasing trend of $\mathrm{SO}_{2}$ concentrations in Central Europe in

Table 1. Percentage distribution of ecological requirements ( $\mathrm{pH}$, light, xerophytism, eutrophication) of epiphytic and epigeic/saxicolous species. On the basis of a 5-class ranking (NImIs and MARTELLOS 2017), each species can be assigned to more than one value. For poleotolerance (three possible classes), each species is assigned only to a single class.

\begin{tabular}{|c|c|c|c|}
\hline $\begin{array}{l}\text { Species eco- } \\
\text { logical trait }\end{array}$ & Classes of ecological traits & $\begin{array}{l}\text { Epiphytic } \\
\text { species } \\
\text { (in \%) }\end{array}$ & $\begin{array}{c}\text { Saxicolous } \\
\text { and epigeic } \\
\text { species (in \%) }\end{array}$ \\
\hline \multirow{5}{*}{$\begin{array}{l}\text { Affinity to } \mathrm{pH} \\
\text { of the substra- } \\
\text { tum }\end{array}$} & on very acid substrata & 33 & 0 \\
\hline & on acid substrata & 95 & 10 \\
\hline & on subacid to subneutral substrata & 86 & 48 \\
\hline & on slightly basic substrata & 29 & 96 \\
\hline & on basic substrata & 10 & 78 \\
\hline \multirow{5}{*}{$\begin{array}{l}\text { Light require- } \\
\text { ments }\end{array}$} & very shaded situations & 5 & 0 \\
\hline & shaded situations & 19 & 8 \\
\hline & $\begin{array}{l}\text { sites with plenty of diffuse light but scarce direct } \\
\text { solar irradiation }\end{array}$ & 71 & 62 \\
\hline & $\begin{array}{l}\text { sun-exposed sites, but avoiding extreme solar irra- } \\
\text { diation }\end{array}$ & 81 & 94 \\
\hline & sites with very high direct solar irradiation & 57 & 72 \\
\hline \multirow{5}{*}{ Xerophytism } & hydro- and hygrophytic species & 10 & 0 \\
\hline & rather hygrophytic species & 52 & 18 \\
\hline & mesophytic species & 95 & 66 \\
\hline & $\begin{array}{l}\text { xerophytic species, but absent from extremely arid } \\
\text { stands }\end{array}$ & 33 & 80 \\
\hline & very xerophytic species & 5 & 26 \\
\hline \multirow{5}{*}{$\begin{array}{l}\text { Tolerance to } \\
\text { eutrophication }\end{array}$} & not resistant to eutrophication & 52 & 40 \\
\hline & resistant to a very weak eutrophication & 71 & 66 \\
\hline & resistant to a weak eutrophication & 71 & 78 \\
\hline & occurring in rather eutrophicated situations & 33 & 44 \\
\hline & occurring in highly eutrophicated situations & 10 & 12 \\
\hline \multirow{3}{*}{ Poleotolerance } & occurring only in natural or semi-natural habitats & 10 & 30 \\
\hline & occurring up to moderately disturbed areas & 33 & 36 \\
\hline & occurring up to heavily disturbed areas & 57 & 34 \\
\hline
\end{tabular}


recent years (LIESKOVSKÁ \& LÉNYIOVÁ 2018). Ecological indicator values for epiphytic species (Table 1) show that the lichen flora is composed of mesophilous species of subacid to subneutral substrata, typical of sites with plenty of diffuse light, up to sun-exposed sites and generally growing in very weakly to moderately eutrophicated environments. Noteworthy, scattered thalli of threatened species, which are generally confined to unpolluted environments, are also present in the area of Krasín. For example, Arthonia radiata (CR), Graphis scripta (EN), and Pyrenula nitida (EN) grow on the base of Fagus trunks, Punctelia subrudecta (EN) on isolated Quercus trees on the ridge of the hill and the endangered Evernia prunastri on shrubs of Prunus spinosa and Acer trees. The presence of these threatened lichens reflects the quality of the forest environment, as such species are considered as indicators of ecological continuity of mountain woodland biotopes in Slovakia and of the low degree of anthropogenic influence (PIšút 1997). In fact, according to the ecological indicator values of poleotolerance, which point to the tendency of a lichen to occur in areas with different degrees of human disturbance (NImis \& MARTELlos 2017), 10\% of the epiphytic species and 30\% of saxicolous and epigeic species are represented by lichens exclusively occurring in natural or semi-natural habitats. The area thus has a relevant value for biodiversity conservation also from the lichenological point of view.

\section{CONCLUSIONS}

A first insight into the lichen flora of the Nature Reserve Krasín (Slovakia) reveals that the presence of typical Central European lichens on calcareous substrates and in mid-altitudinal forests is enriched by the presence of thermophilous elements on south exposed locations. Moreover, forested sites provide suitable conditions for occurrence of rare and threatened species. The results of this lichenological survey thus support the importance of biodiversity conservation in the study area. Concerning the size, heterogeneity, and protected status of the area, further lichenological investigations are highly recommended, especially in the forested area in the western part of the Krasín massif (out of the Nature Reserve, but included in the Natura 2000 site), which was not an object of the present study.

Acknowledgements - The paper is dedicated to DSc Edit Farkas and Dr László Lőkös on the occasion of their 60th birthday. The lichenological survey was conducted within the project of State Nature Conservancy of the Slovak Republic "Vypracovanie programov starostlivosti o vybrané chránené územia zahrnuté v sústave Natura 2000”. The study was also supported by the Scientific Grant Agency of the Slovak Republic (VEGA 2/0032/17). 
Összefoglaló: Jelen közlemény a Nyugati-Kárpátok (Szlovákia) területén található Krasín nevű védett terület és Natura 2000 terület első lichenológiai felmérésének eredményeit közli. A terület változatos élőhelyeket foglal magában, így meszes kibukkanásokat, délies kitettségü száraz lejtőket, tölgyeseket és gyertyán és hárs erdőket, melyek alkalmas élőhelyeket teremtenek kéreglakó, sziklalakó és talajlakó zuzmófajok számára. A vizsgálat során 72 zuzmótaxont sikerült kimutatni a területről, melyek közül 5 vörös könyves faj Szlovákiában, 4 pedig a folyamatos erdőborítást jelző faj.

\section{REFERENCES}

DeváN P. (2001): Doplnky k faune žihadlovkovitých blanokrídlovcov (Hymenoptera, Aculeata) PP Krasín. [Addition to the fauna of Aculeata of the NR Krasín]. - Sborník Prírodovédnébo Klubu v Uherském Hradisti 6: 164-166.

Faš ко P. \& ŠŤAstnÝ P. (2002): Priemerné ročné úbrny zrážok. $1: 2000$ 000. [Mean annual precipitation totals. $1: 2000$ 000]. - In: MI KLós L. \& HrNČIARovÁ T. (eds): Atlas krajiny Slovenskej republiky. [Landscape atlas of the Slovak Republic]. Ministerstvo životného prostredia SR, Slovenská agentúra životného prostredia, Bratislava, Banská Bystrica, p. 99.

GutTovÁ A. \& FAČKovcová Z. (2012): Výskyt druhov Leptogium schraderi a L. turgidum (lichenizované huby) na Slovensku. [Occurrence of the species Leptogium schraderi and L. turgidum (lichenized fungi) in Slovakia]. - Bryonora 50: 2-7.

Guttová A., LAckovičovÁ A. \& Pišút I. (2013): Revised and updated checklist of lichens of Slovakia (May 2013). - Biologia 68: 845-850. + 50 pp. electronic appendix.

LaPIn M., FašKo P., Melo M., ŠŤAst NÝ P. \& Tomlain J. (2002): Klimatické oblasti. 1 : 1000000. [Climatic regions. 1 : 1000 000]. - In: Miklós L. \& HrNČiarová T. (eds): Atlas krajiny Slovenskej republiky. [Landscape atlas of the Slovak Republic]. Ministerstvo životného prostredia SR, Slovenská agentúra životného prostredia, Bratislava, Banská Bystrica, p. 95.

LIESKOVSKÁ Z. \& LÉNYIOvÁ P. (eds) (2018): Správa o stave životného prostredia Slovenskej republiky $v$ roku 2017. [State of the Environment Report of the Slovak Republic 2017]. - Ministerstvo životného prostredia SR, Slovenská agentúra životného prostredia, Bratislava, Banská Bystrica, 218 pp.

LUKÁš J. (2008): Včely (Hymenoptera, Apoidea) prírodnej rezervácie Krasín. [Bees (Hymenoptera, Apoidea) of the Nature Reserve Krasín]. - Naturae Tutela 12: 113-117.

MAJZlan O. (2017): Chrobáky (Coleoptera) prírodnej rezervácie Krasín nad obcou Dolná Súča $\mathrm{v}$ Bielych Karpatoch. [Beetles (Coleoptera) of Nature Reserve Krasín above the village of Dolná Súča in the Biele Karpaty Mts]. - Ochrana prírody, Nature conservation 29: 5-19.

Mišík M., SÝKora M. \& AUbReCht R. (1994): Middle Jurassic scarp breccias with clefts filled by Oxfordian and Valanginian-Hauterivian sediments, Krasín near Dolná Súča (Pieniny Klippen Belt). - Geol. Carpathica 45(6): 343-356.

Natura 2000 Database: Standard data form SKUEV0375 Krasin. Available at: http://natura2000. eea.europa.eu/Natura2000/SDF.aspx?site=SKUEV0375.

Natura 2000 Report: Územie európskeho významu Krasin. - Štátna ochrana prírody SR, Banská Bystrica, 11 pp. Available at: http://www.sopsr.sk/natura/doc/inf_brozury/Krasin.pdf

Nimis P. L \& MARTELlos S. (2017): ITALIC - The Information System on Italian Lichens. Version 5.0. University of Trieste, Trieste. Available at: http://dryades.units.it/italic

PIšÚ T I. (1997): Application of some epiphytic lichens for environmental valorisation of mountain forests in Slovakia. - Biologia 52(1): 23-26. 
PIšÚT I. (1999): Mapovanie rozš́renia epifytických lišajníkov na Slovensku (1970-1981). - Botanický ústav SAV, Bratislava, $120 \mathrm{pp}$.

Pišút I., GutTová A., LACKovičová A. \& Lisická E. (2001): Červený zoznam lišajníkov Slovenska (december 2001). - In: BALÁž D., MARHOLD K. \& URBAN P. (eds): Červený zoznam rastlín a živočíchov Slovenska. - Ochrana Prírody 20 (Suppl.): 23-30.

ŠŤast NÝ P., NiePlová E. \& Melo M. (2002): Priemerná ročná teplota vzduchu. $1: 2000$ 000. [Mean annual air temperature. $1: 2000$ 000]. - In: MikLós L. \& Hrnčiarová T. (eds): Atlas krajiny Slovenskej republiky. [Landscape atlas of the Slovak Republic]. Ministerstvo životného prostredia SR, Slovenská agentúra životného prostredia, Bratislava, Banská Bystrica, p. 98.

(submitted: 29.09.2019, accepted: 08.11.2019) 